\title{
Penerapan pembelajaran Team-Assisted Individualization (TAI) berbasis tahapan Newman untuk meningkatkan kemampuan siswa kelas VII SMP Brawijaya Smart School dalam menyelesaikan soal cerita matematika
}

\author{
Winda Ratna Siswaningtyas, Tri Hapsari Utami* \\ Universitas Negeri Malang, Jl. Semarang No. 5 Malang, Jawa Timur, Indonesia \\ *Penulis korespondensi, Surel: trihapsariutami.fmipa@um.ac.id
}

Paper received: 01-12-2021; revised: 15-12-2021; accepted: 31-12-2021

\begin{abstract}
the aim this research is to know applying Team-Assisted Individualization (TAI) based Newman Stages can increase ability of students to solving mathematics world problems. Data collected with document analysis and observation with descriptive qualitative approach. The result shows that the number of students in high-ability increase 42,43 percent and the number of students in lowability decrease $33 \%$, group distribution based on prior-ability and characteristic of students, the teacher assist student getting into difficulty, groups of learning to fare well, reflection of learning can unbend misconseption of students, and the appreciation be a motivation of students in learning
\end{abstract}

Keywords: pembelajaran Team-Assisted Individualization (TAI); Tahapan Newman; Soal Cerita Matematika.

\section{Pendahuluan}

Soal cerita matematika adalah suatu permasalahan yang timbul dalam kehidupan sehari - hari yang berkaitan dengan konsep pelajaran matematika. Berdasarkan observasi awal yang dilakukan peneliti di kelas VII SMP Brawijaya Smart School menunjukkan bahwa cukup banyak siswa yang masih mengalami kesulitan dalam menyelesaikan soal cerita matematika dan beberapa siswa yang memiliki kemampuan tinggi memiliki sifat individual. Selain itu, dalam kegiatan pembelajaran guru lebih cenderung menjelaskan langkah pengerjaan kemudian siswa diminta untuk mengerjakan latihan soal. Oleh karena itu, perlu adanya pembelajaran yang dapat mengatasi kesulitan siswa dalam menyelesaikan soal cerita dan mengoptimalkan kerja masing - masing individu dalam kelompok, yaitu dengan menerapkan Pembelajaran Team-Assisted Individualization (TAI) Berbasis Tahapan Newman. Tujuan penelitian ini adalah Penerapan Pembelajaran Team-Assisted Individualization (TAI) Berbasis Tahapan Newman yang bagaimanakah yang dapat meningkatkan kemampuan siswa dalam menyelesaikan soal cerita matematika.

Team-Assisted Individualization (TAI) merupakan suatu program yang mengkombinasikan pembelajaran kooperatif dengan pengajaran individual untuk memenuhi kebutuhan kelas yang berbeda - beda (Slavin, 1989). Widdiharto (2004) menyatakan bahwa Slavin membuat model pembelajaran Team-Assisted Individualization (TAI) adalah mengkombinasikan keunggulan kooperatif dan pengajaran individu, memberikan pengaruh sikap sosial dari belajar kooperatif, dan disusun untuk memecahkan masalah dalam program pengajaran misalnya dalam hal kesulitan belajar siswa secara individual. Kriteria dari model pembelajaran Team-Assisted Individualization (TAI) menurut Slavin, dkk (1983), antara lain dapat meminimalisir keterlibatan guru dalam pengelolaan rutin, penerapan model pembelajaran sederhana, siswa akan termotivasi untuk mempelajari materi - materi yang akan diberikan dengan cepat dan akurat, dan tidak akan bisa berbuat curang atau 
menemukan jalan pintas, tersedianya banyak cara pengecekan penguasaan, programnya tidak mahal, fleksibel, dan mudah dipelajari, dan dapat membentuk sikap positif siswa. Komponen utama dari model pembelajaran Team-Assisted Individualization (TAI) menurut Slavin, dkk (1989), yaitu placement test, team, curriculum materials, teaching groups, team study method, fact test, whole-class units, dan team score and team recognition.

Prakitipong \& Nakamura ( 2006) menyatakan bahwa, "The Newman procedure is a method that analizes errors in sentence problem", Prosedur/Tahapan Newman adalah metode yang digunakan untuk menganalisis kesalahan pada permasalahan kalimat. Newman (1977, 1983) dalam White (2010:129) "defined five specific reading skills as crucial to performance on mathematical word problems. They are reading, comprehension, transformation, process skills, and encoding", didefinisikan lima keterampilan membaca secara spesifik yang penting untuk memecahkan permasalahan nyata matematis, yaitu membaca, memahami, transformasi, keterampilan proses, dan penulisan jawaban akhir.

Haji (1994) yang menyatakan bahwa "untuk mengukur indikator pencapaian pemahaman siswa adalah dengan pemberian soal matematika". Ada beberapa jenis soal yang bisa digunakan untuk mengukur indikator pencapaian siswa, salah satunya adalah jenis soal cerita matematika. Soal cerita matematika merupakan salah satu jenis latihan soal matematika yang berbentuk cerita. Soal cerita matematika ini adalah suatu permasalahan yang timbul dalam kehidupan sehari - hari berkaitan dengan konsep pelajaran matematika. langkah - langkah sistematis untuk menyelesaikan masalah (Hudojo dan Sutawijaya, 2005), yaitu pemecahan terhadap masalah, perencanaan penyelesaian masalah, melaksanakan perencanaan penyelesaian masalah, dan melihat kembali penyelesaian.

1. Langkah penerapan Pembelajaran Team-Assisted Individualized (TAI) Berbasis Tahapan Newman adalah sebagai berikut : Placement Test, siswa diberikan pre-test yang dikerjakan secara mandiri, kemudian hasil dari pre-test tersebut digunakan sebagai pedoman untuk mengelompokkan siswa.

2. Team, siswa dibagi menjadi kelompok heterogen yang terdiri dari $4-5$ siswa.

3. Curriculum Materials, siswa diberikan lembar bertanya dan lembar kerja yang berisikan soal cerita matematika yang harus diselesaikan menggunakan Tahapan Newman berikut:

a. Tahapan Membaca, siswa diminta untuk menuliskan kata kunci dari permasalahan.

b. Tahapan Memahami, siswa diminta untuk menuliskan apa yang diketahui dan apa yang ditanyakan.

c. Tahapan Transformasi, siswa diminta untuk menuliskan metode apa yang akan digunakan.

d. Tahapan Keterampilan Proses, siswa diminta untuk menuliskan prosedur penyelesaian secara sistematis.

e. Tahapan Penulisan Jawaban Akhir, siswa diminta untuk menuliskan jawaban akhir yang disesuaikan dengan konteks permasalahan. 
4. Teaching Groups, guru berkeliling ketiap tim/kelompok untuk membantu siswa yang mengalami kesulitan.

5. Team Study Method, siswa mengerjakan Lembar Kerja yang telah diberikan oleh guru, kemudian melakukan pengecekan jawaban.

6. Fact Test, siswa diberikan soal tes.

7. Whole-Class Units, guru bersama siswa melakukan refleksi pembelajaran.

8. Team Score And Team Recognition, guru memberikan penghargaan kepada siswa yang memiliki skor tinggi

Sesuai kurikulum 2013, materi perbandingan untuk kelas VII SMP memuat 3 kompetensi dasar. Pada kompetensi dasar 4.4 materi perbandingan, siswa diharapkan mampu untuk menggunakan konsep perbandingan untuk menyelesaikan masalah nyata dengan menggunakan tabel dan grafik. Untuk memenuhi kompetensi tersebut, maka dibutuhkan soal matematika yang menghubungkan konsep materi perbandingan dengan permasalahan nyata atau permasalahan dalam kehidupan sehari - hari yaitu dengan memberikan soal cerita matematika.

\section{Metode}

Pendekatan yang digunakan dalam penelitian ini adalah pendekatan kualitatif deskriptif dengan jenis Penelitian Tindakan Kelas (PTK). Pada penelitian ini, peneliti menggunakan 4 tahapan dalam melaksanakan Penelitian Tindakan Kelas (PTK) menurut Kurt Lewin, yaitu a) perencanaan/planning, b) tindakan/acting, c) pengamatan/observing, dan d) refleksi/reflecting (Kusumah, 2012). Penelitian ini dilakukan pada tanggal 26 Oktober - 4 November 2015 dengan subjek dan lokasi penelitiannya adalah siswa kelas VIIE SMP Brawijaya Smart School yang berjumlah 21 siswa.

Pada penelitian ini, peneliti bertindak sebagai pengumpul data, penganalisis data, dan penyusun serta pelapor hasil penelitian, serta berperan sebagai pemberi tindakan dan observer dalam proses pembelajaran. Untuk melakukan observasi terhadap pemebelajaran, peneliti akan dibantu oleh guru matematika dan teman sejawat.

Instrumen penelitian yang digunakan dalam penelitian ini adalah Lembar Observasi digunakan untuk mengamati kegiatan siswa ketika pembelajaran berlangsung, Lembar Catatan Lapangan yang digunakan untuk melengkapi data yang telah terekam dalam lembar observasi dan bersifat penting sehubungan dengan kegiatan pembelajaran, dan wawancara tidak terstruktur untuk memverifikasi hasil observasi yang telah dilakukan. Sedangkan instrumen pembelajarannya, antara lain Rencana Pelaksanaan Pembelajaran (RPP) untuk merencanakan pembelajaran yang akan dilakukan, Lembar Soal Tes, Lembar Kerja Siswa yang membantu guru dalam mengajarkan materi yang diajarkan sehingga sesuai dengan tujuan yang telah ditetapkan, Rubrik Penilaian merupakan panduan penilaian yang berupa skor deskriptif yang mengacu pada indikator yang akan diamati, Lembar Validasi yang digunakan untuk mengukur kelayakan perangkat yang akan digunakan dalam penelitian.

Pengumpulan dilakukan melalui tes dan observasi. Pada penelitian ini, tes diperlukan sebagai alat pemantau kemampuan siswa dalam menyelesaikan soal cerita matematika. Tes yang digunakan adalah tes penempatan (pre-test) untuk dijadikan pedoman dalam 
mengelompokkan siswa dan tes akhir tindakan digunakan untuk mengetahui peningkatan kemampuan siswa dalam menyelesaikan soal cerita matematika. Sedangkan observasi dilakukan dengan tujuan untuk mengamati aktivitas siswa dan pengajar selama pembelajaran apakah sesuai dengan apa yang diharapkan/direncanakan.

Analisis data dilakukan setiap kali setelah pemberian suatu tindakan dan semua data yang diperlukan telah terkumpul. Data yang dianalisis meliputi : hasil tes siswa, hasil observasi, dan hasil catatan lapangan yang dianalisis secara deskriptif untuk mengetahui pelaksanaan pembelajaran, kesalahan - kesalahan yang dilakukan, dan kesesuaian bantuan guru yang diberikan dalam memperbaiki kesalahan tersebut. Pada penelitian ini, peneliti menganalisis data dengan langkah dari Miles and Huberman, yaitu Reduksi Data yang berarti merangkum, memilih hal - hal yang pokok, memfokuskan pada hal - hal yang penting, dicari tema dan polanya (Sugiyono, 2011), Penyajian Data yang disajikan dalam bentuk teks naratif yang mendeskripsikan pelaksanaan pembelajaran Team-Assisted Individualization (TAI) Berbasis Tahapan Newman serta kemampuan siswa dalam menyelesaikan soal cerita matematika, serta menarik kesimpulan dan verifikasi.

\section{Hasil dan Pembahasan}

\subsection{Hasil}

Nilai rata - rata yang diperoleh siswa pada Tes I dan Tes II menunjukkan bahwa banyak siswa yang berkemampuan tinggi meningkat dari $29 \%$ menjadi $71,43 \%$ atau peningkatannya sebesar $42,43 \%$, sedangkan banyak siswa yang berkemampuan rendah berkurang dari $33 \%$ menjadi $0 \%$ atau berkurang sebesar $33 \%$.

Penerapan Pembelajaran Team-Assisted Individualization (TAI) berbasis Tahapan Newman yang dilakukan oleh peneliti adalah Placement Test dilakukan dengan memberikan pre-test. Dikarenakan dalam penerapannya ada beberapa siswa yang berbuat curang dan tidak mengikuti tes, maka pengelompokkan didasarkan pada Nilai Tengah Semester bukan nilai pre-test. Team, mengelompokkan siswa menjadi beberapa kelompok heterogen yang beranggotakan 4 - 5 siswa dan pengelompokkan didasarkan kemampuan dan karakteristik siswa, sehingga siswa dapat melakukan diskusi dengan baik. Curriculum Materials pemberian Lembar Kerja yang berisikan soal cerita matematika yang diselesaikan menggunakan Tahapan Newman dan Lembar bertanya sebagai pengontrol siswa dalam diskusi, sehingga mendorong siswa untuk bertanya kepada teman satu kelompok ketika mengalami kesulitan dan siswa lain dapat membantu temannya.

Pada kegiatan Teaching Groups, guru memberikan bantuan kepada siswa yang mengalami kesulitan. Bantuan yang diberikan guru dapat meluruskan kesalahan yang dilakukan siswa, serta dapat membantu siswa memahami materi lebih dalam. Bantuan yang diberikan oleh guru pada tiap Tahapan Newman adalah Tahapan Membaca, bantuan yang diberikan guru adalah meminta siswa untuk mencari suatu kata yang mengindikasikan inti dari permasalahan yang ada pada soal cerita. Tahapan Memahami, bantuan yang diberikan guru adalah meminta siswa untuk membaca dan memahami permasalahan yang ada pada soal cerita dengan cara menceritakan kembali permasalahan tersebut dengan kata - katanya sendiri, kemudian siswa diminta untuk menentukan apa yang diketahui dan apa yang ditanyakan dari permasalahan tersebut. Tahapan Transformasi, bantuan yang diberikan guru adalah guru mengingatkan kembali tentang ciri - ciri soal cerita yang menggunakan konsep perbandingan senilai dan perbandingan berbalik nilai. Tahapan Keterampilan Proses, bantuan 
yang diberikan guru adalah meminta siswa untuk membuat tabel atau menggunakan rumus guna menyelesaikan permasalahan tersebut. Tahapan Penulisan Jawaban Akhir, bantuan yang diberikan guru adalah meminta siswa untuk membuat hubungan antara apa yang ditanyakan dan hasil yang ditemukan.

Team Study Method, siswa mengerjakan Lembar Kerja yang disediakan dan bertanya kepada teman atau guru apabila mengalami kesulitan. Kegiatan diskusi kelompok berjalan dengan baik, sehingga siswa dapat mengerjakan tugasnya dengan baik. Kemudian siswa melakukan pengecekan jawaban. Fact Test, dilakukan tes kemampuan menyelesaikan soal cerita matematika menggunakan Tahapan Newman yang dikerjakan secara individu. Tes berjalan dengan baik karena siswa serius mengerjakan tesnya masing - masing dan tidak terlihat siswa yang berbuat curang. Whole-Class Units, guru beserta siswa melakukan refleksi pembelajaran. Dengan adanya refleksi pembelajaran ini siswa bisa meluruskan kesalahan yang dilakukan. Hampir semua siswa memperhatikan guru ketika memberikan penjelasan. Team Score and Team Recognition, pemberian penghargaan kepada kelompok yang memiliki skor tinggi. Pemberian penghargaan ini memotivasi siswa untuk berusaha lebih keras dalam mengerjakan tugas yang diberikan dan saling membantu teman dalam satu kelompok

Persentase kesalahan siswa paling banyak dilakukan pada tahapan transformasi dan tahapan penulisan jawaban akhir. Hal ini dapat dilihat dari banyaknya siswa yang tidak tepat dalam menuliskan metode pada Tes I sebanyak $28,57 \%$ dan banyaknya siswa yang tidak tepat dalam menuliskan jawaban akhir pada Tes II sebanyak $28,57 \%$.

Hal - hal yang perlu diperhatikan dalam pembelajaran, antara lain pengkondisian siswa ketika pembelajaran atau tes berlangsung, manajemen waktu, dan pemberian bantuan kepada siswa yang mengalami kesulitan.

\subsection{Pembahasan}

Dalam pembelajaran TAI, komponen yang berpengaruh atas meningkatnya kemampuan siswa, antara lain Team, Teaching Groups, dan Team Study Method. Pemilihan anggota Team/tim yang disesuaikan dengan kemampuan dan karakteristik siswa membuat belajar kelompok berjalan dengan baik, mereka saling bekerjasama dan saling membantu teman satu kelompok dalam menyelesaikan tugas yang diberikan. Hal ini sesuai dengan Widdiharto (2004) yang menyatakan bahwa Slavin membuat model pembelajaran TeamAssisted Individualization (TAI) adalah memberikan pengaruh sikap sosial dari belajar kooperatif. Sikap sosial yang dimaksud adalah sikap siswa yang dapat bekerjasama dan saling membantu teman satu kelompok untuk menyelesaikan tugas yang diberikan oleh guru.

Pemberian bantuan pada komponen Teaching Groups dapat membantu siswa ketika mengalami kesulitan, sehingga siswa bisa mengerti kesalahan yang dilakukan dan melakukan perbaikan. Bantuan yang diberikan, antara lain Tahpam Membaca guru meminta siswa untuk mencari suatu kata yang mengindikasikan inti dari permasalahan, Tahapan Memahami guru meminta siswa untuk membaca dan memahami permasalahan yang ada pada soal cerita dengan cara menceritakan kembali permasalahan tersebut dengan kata - katanya sendiri, Membaca ulang permasalahan dan mengidentifikasi apa yang diketahui dalam permasalahan tersebut merupakan cara untuk memahami suatu masalah (Hudojo dan Sutawijaya, 2005), Tahapan Transformasi guru mengingatkan kembali tentang ciri - ciri soal cerita yang menggunakan konsep perbandingan senilai dan perbandingan berbalik nilai, Tahapan 
Keterampilan Proses guru meminta siswa untuk membuat tabel atau menggunakan rumus guna menyelesaikan permasalahan tersebut. Membuat suatu tabel atau menggunakan rumus merupakan strategi pemecahan masalah menurut Wheeler (1992) dalam Hudojo (2005), Tahapan penulisan Jawaban Akhir guru meminta siswa untuk membuat hubungan antara apa yang ditanyakan dan hasil yang ditemukan. Menginterpretasikan jawaban yang diperoleh merupakan salah satu cara untuk mereview suatu permasalahan (Hudojo dan Sutawijaya, 2005). Diskusi kelompok pada Team Study Method berjalan dengan baik, sehingga tugas yang diberikan oleh guru dapat dikerjakan dengan baik.

White (2010) menyatakan bahwa dengan menggunakan Analisis Kesalahan Newman guru dapat mengetahui alasan mendasar kesulitan siswa dalam menyelesaikan permasalahan nyata matematika dan menentukan dimana letak terjadinya kesalahan. Persentase kesalahan siswa pada penelitian ini paling banyak dilakukan pada tahapan transformasi dan tahapan penulisan jawaban akhir, sehingga guru harus memberikan bantuan yang lebih optimal dalam membelajarkan tahapan tersebut.

Hal yang perlu diperhatikan, antara lain pengkondisian siswa yang mana guru harus bisa mengontrol siswa agar bisabelajar dengan baik dan tidak bermain sendiri, manajemen waktu yang tepat supaya semua yang direncanakan bisa dilakukan dengan tepat sesuai rencana, dan pemberian bantuan yang optimal agar siswa yang mengalami kesulitan bisa tertangani dengan baik.

\section{Simpulan}

Penerapan Pembelajaran Team-Assisted Individualization (TAI) berbasis Tahapan Newman yang dapat meningkatkan kemampuan siswa dalam menyelesaikan soal cerita matematika adalah placement test dilakukan pre-test. Team mengelompokkan siswa secara heterogen yang didasarkan kemampuan dan karakteristik siswa. Curriculum materials pemberian Lembar Kerja dan lembar Bertanya. Teaching groups pemberian bantuan dari guru untuk siswa yang mengalami kesulitan. Bantuan yang diberikan antara lain Tahapan Membaca dan Tahapan Memahami siswa diminta membaca ulang permasalahan dan menceritakan kembali permasalahannya dengan kata - katanya sendiri kemudian siswa diminta menentukan kata kunci, apa yang diketahui, dan apa yang ditanyakan, Tahapan Transformasi guru mengingatkan kembali tentang ciri - ciri soal cerita yang menggunakan konsep perbandingan senilai atau berbalik nilai. Tahapan Keterampilan Proses siswa diminta untuk membuat tabel atau menggunakan rumus, Tahapan Penulisan Jawaban Akhir siswa diminta untuk membuat hubungan antara apa yang ditanyakan dan hasil yang ditemukan. Team Study Method siswa melakukan diskusi, selanjutnya melakukan pengecekan. Fact Test guru memberikan tes kemampuan soal cerita matematika kepada siswa yang dikerjakan secara mandiri. Whole-Class Units guru beserta siswa melakukan refleksi pembelajaran. Team Score and Team Recognition pemberian penghargaan kepada kelompok yang memiliki skor tertinggi.

Pembelajaran Team-Assisted Individualization (TAI) berbasis Tahapan Newman dapat dijadikan sebagai alternatif untuk membelajarkan siswa dalam menyelesaikan soal cerita matematika. Bagi peneliti lain yang ingin mengembangkan penelitian ini hendaknya menggunakan hasil pekerjaan siswa dalam menyelesaikan soal cerita matematika untuk menentukan kemampuan awal siswa. 


\section{Daftar Rujukan}

Haji, S. (1994). Diagnosis kesulitan siswa dalam menyelesaikan soal cerita di kelas V SD Negeri Percobaan Surabaya (Doctoral dissertation, Tesis. Malang, Indonesia: IKIP Malang).

Hudojo, H. (2005). Pengembangan kurikulum dan pembelajaran matematika. Malang: UM PRESS

Kusumah, W., \& Dwitagama, D. (2012). Mengenal penelitian tindakan kelas. edisi kedua. Jakarta: PT Indeks.

Prakitipong, N., \& Nakamura, S. (2006). Analysis of mathematics performance of grade five students in Thailand using Newman procedure. Journal of International Cooperation in Education, 9(1), 111-122.

Sugiyono. (2011). Metode penelitian kuantitatif kualitatif dan R\&D. Bandung: Alfabeta

Slavin, R. E. (1983). Team-assisted individualization: a cooperative learning solution for adaptive instruction in mathematics.

Slavin, Robert E., Madden, Nancy A. dan Robert J. Stevens. (1989, Desember). Cooperative learning models for the 3R's, 22 - 28. http://www.ascd.org/ASCD/pdf/journals/ed_lead/el_198912_slavin2.pdf

White, A. L. (2010). Numeracy, literacy and newman's error analysis. Journal of Science and Mathematics Education in Southeast Asia, 33(2), 129-148.

Widdiharto.(2004). Model - model pembelajaran. Jakarta : Gema Pena 